\title{
Indigenous Knowledge of Ecological Variability and Commons Management: A Case Study on Berry Harvesting from Northern Canada
}

\section{Brenda Parlee • Fikret Berkes • \\ Teetl'it Gwich'in Renewable Resources Council}

Published online: 28 October 2006

(C) Springer Science + Business Media, LLC 2006

In the article XML, Teetl'it Gwich'in Renewable Resource Council should be listed only once, after the names of coauthors Brenda Parlee and Fikret Berkes (not before their names as well).

The online version of the original article can be found at: http://dx.doi.org/10.1007/s10745-006-9038-9.

B. Parlee $(\bowtie) \cdot$ F. Berkes

Natural Resources Institute, University of Manitoba, 70 Dysart Rd.,

Winnipeg, MB R3T2N2, Canada

e-mail: brenda.parlee@ualberta.ca

Present address:

B. Parlee

Faculty of Native Studies/Department of Rural Economy, AFHE,

507 GSB, Edmonton, AB T6G2H1, Canada

Teetl'it Gwich'in Renewable Resources Council

Box 30, Fort McPherson, NT X0E 0J0, Canada 